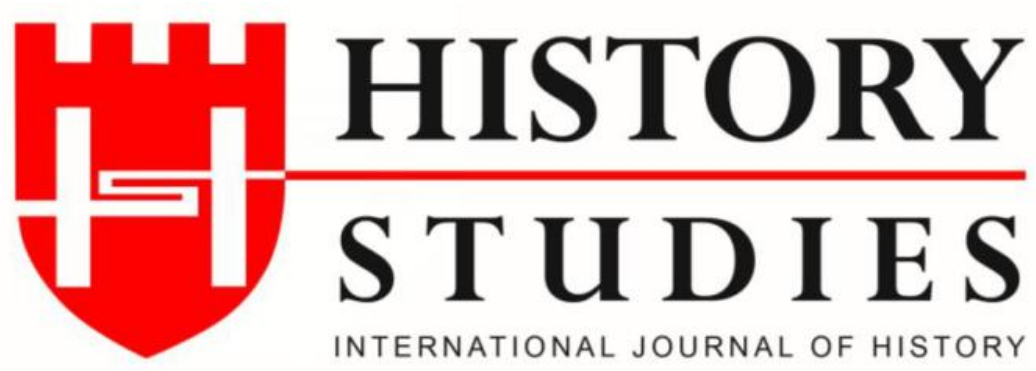

\author{
ISSN: 13094173 (Online) 1309 - 4688 (Print) \\ Volume 12 Issue 3, June 2020 \\ DOI Number: 10.9737/hist.2020.879 \\ Araştırma Makalesi \\ Makalenin Geliş Tarihi: 19.04.2020 Kabul Tarihi: 05.05.2020 \\ Atıf Künyesi: İsmet Türkmen, “Köy Enstitüleri Araştırmaları Üzerine Metodolojik Bir Yaklaşım”, \\ History Studies, 12/3, Haziran 2020, s. 1315-1333.
}

\title{
Köy Enstitüleri Araştırmaları Üzerine Metodolojik Bir Yaklaşım
}

\section{A Methodological Approach on Village Institutes Research}

\author{
Doç. Dr. İsmet Türkmen \\ ORCID No: 0000-0002-8198-5707 \\ Tokat Gaziosmanpaşa Üniversitesi
}

Öz: Türkiye'de Köy Enstitüleri denemesi yaklaşık 80 yıldır siyasetten eğitime, iktisattan sosyal yaşama farklı çevrelerin tartışmalarının merkezinde yer almaktadır. Bazı çevrelerce özlemle anılan bazıları tarafından da hakkında yoğun spekülasyonlar yapılan Köy Enstitüleri, politik kutuplaşmalara neden olurken Türk siyasetinde yol ayrımlarına da yol açmıştır. Bu bağlamda tarihi deneyimimizde bu kurumlar kadar tartışlagelen çok az sayıda mesele vardır. Özellikle Türk demokrasisinde köklü değişimlerin yaşandığı 1950'li ve 1960'lı yıllarda, yoğun siyasî ve ideolojik tartışmaların merkezinde bu enstitülerin mevcudiyeti yer almıştır. Bu çalı̧̧mada Köy Enstitüleri konusunun, sözlü tarih araştırmaları için özel ve güçlü yanları ve potansiyelleri olduğu kanaatindeyiz. Şüphesiz, bu kurumlarda idarecilik yapmış, ders vermiş, öğrenim görmüş, memuriyette bulunmuş, bu kurumların yerleștiği coğrafyaların yakınlarındaki köylerde bulunmuş herkesin anlatacak tarihî ve sosyal açıdan ilginç yaşam öyküleri vardır. Bu kurumların varlıklarını devam ettirdikleri dönemde, lehinde ve aleyhinde tavır alan toprak sahipleri ve bürokratların, bu alanda çalışan entelektüel kesimlerin fikirleri ve dayanakları, bu konudaki spekülasyonların açığa kavuşturulması açısından fevkalade mühimdir. Bu doğrultuda; 1940-1954 yılları arasında Köy Enstitüleri'ne ilişkin TBMM arşiv kayıtlarından, dönemin süreli yayınlarından, telif ve tetkik eserlerden de yararlanılmıştır.

\section{Anahtar Kelimeler: Köy Enstitüleri, Türkiye, Sözlü Tarih, Kırsal Kalkınma}

Abstract: Village Institutes trial in Turkey for nearly 80 years is located in the center of discussion of different circles from politics to education and from economics to social life. Village Institutes, that some people have long been reckoned with and some others have been speculated about, have caused polarization and separations in Turkish politics. In this context, there are very few issues in our historical experience that are discussed as much as these institutions. Especially in the 1950s and 1960s when the radical changes were experienced in Turkish democracy, the existence of these institutes was the center of intense political and ideological debates. This study argues that the subject of Village Institutes has special strenghts and potantial for verbal history researchs. Undoubtedly, everybody who has worked, taught, been educated, been in service in this institutes and has lived in the villages near the geographies where these institutions were located, has historical and socially interesting life stories to tell. The ideas and grounds of the landowners and bureaucrats who took a stand in favor of and against these institutions during the period when these institutions continued their existence and the examinations of intellectuals working in this field are extremely important in terms of revealing the speculation on this matter. In this study the 
documents and records about Village Institutes from Prime Ministry Republic Archive, and parliamentary records, periodicals of the period, copyright and audit works were used.

Keywords: Village Institutes, Turkey, Verbal History, Rural Development

\begin{abstract}
“Olayların içine böylece sızıp, dile getirdikleri düşünceyi ortaya çıkarmakla, tarihçi bilim adamının yapması gerekmeyen ve yapmayacă̆ bir şey yapar. Bu anlamda tarihçinin işi, bilim adamınınkinden daha karmaşıktır. Bir başka anlamda ise daha yalın; tarihçinin olayların nedenlerini yada yasalarını ararken (tarihçi olmayı bırakmadan)bilim adamına öykünmesine gerek yoktur, öykünemez de. Bilim için olay, onu algllayarak keşfedilir, nedeni konusundaki daha ileri araştırma ise, onu sınıfina bağlayarak ve o sınıf ile öteki sınıflar arasındaki ilişkiyi belirleyerek sürdürülür. Tarih için, keşfedilecek nesne salt olay değil, onda dile gelen düşüncedir. $O$ düşünceyi keşfetmek zaten onu anlamaktır. Tarihçinin olguları belirlemesinden sonra, nedenleri soruşturmak gibi fazladan bir süreç yoktur. Tarihçi ne olup bittiğini bilince, neden olup bittiğini zaten bilir,"l
\end{abstract}

R.G. Collingwood

\title{
Giriş
}

1937 ile 1946 döneminin eğitim deneyimi özelinde siyasî ve ideolojik tartışmaların odak noktası hakkında şu ifadelere yer vermektedir: "Köy Enstitüleri Sol-Kemalistlere göre gerçek Kemalizm'in doruk noktasını temsil etmiş, sağcı ve muhafazakâr çevreler içinse kendi siyasal çıkarları ve anti-komünist cadı kazanları için bir günah keçisi olmuştur. Köy Enstitüleri ünlü Romancımı Kemal Tahir gibi sosyalist düşünceye yakın kişiler tarafindan Tek Parti rejiminin ideolojisini yaymak amacıyla oluşturulmuş faşizan kurumlar olarak algılanmış ve şiddetle eleştirilmiştir. "’2 $\mathrm{Bu}$ ifadelerden de anlaşılacağı üzere, Türkiye'de pek az kurum bu türden farklı değerlendirilmelere konu olmuştur. Bu bağlamda gerek Türkiye'de gerekse diğer ülkelerde enstitüleri konu alan bunca çalışma yapılmasına rağmen bu kurumlar tam anlamı ile anlaşılabilmiş değildir. Bu kurumların üzerinde tartışmaların hala güncelliğini muhafaza ediyor olması arşiv kaynaklarını merkeze alan yeni çalışmaları gerektirirken, diğer yandan kurumların siyaset merkezli tartışmalara tabi oluşu enstitülerin üzerinde durulmasını güçleştirmektedir. Ayrıca, bir eğitim kurumu tarihîni araştırmanın ötesine geçen Köy Enstitülerini araştırmamızın arkasındaki gerçeklik, enstitülerin kuruluş sürecini teşkil eden 1940'lı yılların sosyo-kültürel tarihîni de araştırmayı gerektirmektedir.

\section{Türkiye'de Bir Sözlü Tarih Alanı: Köy Enstitüleri}

Hangi tarihî olguların sözlü tarih araştırma çalışmaları için özel ve güçlü yanları olduğu sorusuna Paul Thompson farklı noktalardan bakmaktadır: Bunlar; gizli kalmış sesler, gizli kalmış alanlar, sözlü gelenekler ve yaşamlar yoluyla bağlantılar kurmaktır. ${ }^{3}$ Araştırmamızın merkezinde yer alan ülkemizdeki Köy Enstitüleri denemesinin bahsi geçen dört maddelerle doğrudan ilişkilendirilebileceği düşünülebilir. Örneğin sözlü tarih yöntemi ile, enstitülere tanıklık etmiş çok az kişinin hayatları kayıtlarla belgelenebildiği için sesleri gizli kalmış kişilerin tecrübelerine erişmemizi sağlamaktadır. Bu gizli kalmış sesler bizzat enstitülerin insan

${ }^{1}$ R.G. Collingwood, Tarih Tasarımı, (Çev: Kurtuluş Dinçer), Gündoğan Yayınları, Ankara 1996, s. 21.

2 Asım Karaömerlioğlu, Orada Bir Köy Var Uzakta (Erken Cumhuriyet Döneminde Köycü Söylem), 2. Baskı, İletişim Yayınları, İstanbul 2011, s. 87.

${ }^{3}$ Paul Thompson, "21. Yüzyılda Sözlü Tarih İçin Potansiyeller ve Meydan Okumalar", Kuşaklar Deneyimler Tanıklar: Türkiye'de Sözlü Tarih Çalışmaları Konferansı (26-27 Eylül 2003), (Yay. Haz: Aynur İlyasoğlu-Gülay Kayacan), İstanbul 2006, s. 27. 
kaynağını teşkil eden öğrencileri, idarecileri veya idari personelidir. Bu bağlamda öğrenciler özelinde kurumların belgelere yansımamış veya yansıtılamamış gerçekliklerini sözlü tarih çalışmaları ortaya koyabilmektedir.

Ülkemizde sözlü tarih çalışmaları özelinde yeterince çalışılmadığını düşündüğümüz potansiyel bir alan da Köy Enstitüleri'nde din ve günlük hayat arasındaki karşılıklı ilişkidir. Esasında bu ilişkiyi merkeze alan bir çalışmaya yönelinmesi halinde, Türkiye'de gerek enstitülerin kuruluş süreçleri ve tarihî arka planındaki algı gerekse kapatılış süreçlerine dair yönelimler dönemin din-devlet-eğitim mefhumları arasındaki ilişkileri anlamlandırmak açısından önemli oldurdu. Ayrıca, sözlü tarihîn insanlar arasında bağlantı kurmadaki özel önemini düşünmek gerekmektedir. Örneğin enstitüler eğitim tarihî çalışmalarından daha ziyade siyasî tarih araştırmalarının konusu olmuştur. Bu bağlamda, konu özelinde tarih ve siyaset bilimi arasında çok yakın bir ilişkinin olduğu söylenebilir. Öyle ki, tarihe, "geçmişteki siyaset", siyasete de "bugünkü siyaset" gözü ile bakılabilir. Fakat burada göz ardı edilmemesi gereken husus enstitülerin çalışılması sırasında, araştırmacılar için gerekli malzemeyi sağlayan siyasî tarih sayesinde, bir sosyal bilimci "tarihî bakış" kullanmak suretiyle bu müesseseler ve siyaset arasındaki ilişkileri tetkîk eder, açıklamalarda ve yorumlarda bulunur. Diğer bir ifade ile; öncelikle enstitülerin kuruluş süreci ve gelişim aşamaları, dönemin siyasî ve sosyo-kültürel şartları "geleneksel hadise naklinin" yerine, "analitik tarihî", ikame etmek; ikinci olarak temelde siyasî olan bir anlatımın yerine, bütün beşerî faaliyetleri kucaklayan bir tarihî koymak gerekmektedir: Son olarak ilk iki hedefe ulaşabilmek için, diğer disiplinlerle işbirliği yapmak gerekmektedir. Bu sayede enstitü araştırmalarında, mantıklı bir analize yer verilmiş olur.

Köy Enstitüleri deneyimi açıklamak için atılan adımlardan ilki Enstitüleri doğuran tarihî arka planı kurgulamak içindir. Örneğin, enstitülerin arka planındaki düşünce birikimini biçimlendiren köycülük ideolojisini hesaba katmadan bilim adamlarınca yapılan değerlendirmeler sebebiyle, bu kurumların gerçek doğasını kavramakta başarısız olunmaktadır.

\section{Köy Enstitülerinin Açılmasının Fikri Temelleri}

Türkiye'de Cumhuriyet idaresinde öğretmen yetiştirme konusu başlıca eğitim sorunlarından birisi olmakla birlikte özellikle nüfusun büyük bir kısmının kırsalda yaşaması sebebiyle bu konudaki çözüm arayışlarının daha önceki yıllara dayandığı bilinmektedir5. Askeri zaferi takip eden günlerde 17 Şubat 1923 tarihinde İzmir'de toplanan Türkiye İktisat Kongresi'nde ziraat ve bu doğrultuda köy eğitimi ile ilgili kararlar da alınmıştır. Ziraat ve maarif meselesine dair alınan kararlar arasında; "Madde 6: Köylerdeki ibtidai ilkokullarının geniş bahçelerinin, ahır ve kümeslerinin olması gerektiğiydi. Bunlar ögretmen denetiminde ögrenciler tarafindan işletilmeli ve böylece çiftçilik çocuklara "amelì" olarak ögretilmeliydi. Yine orta ve yüksek okulları bitiren erkek ve ku ögrenciler ve medrese mezunları köylere giderek en az bir yıl ögretmenlik yapmalılardl. "6 Kongrede saptanan hedeflerden de anlaşllacağı üzere, öğretmen eğitiminde temel amaç çok sayıda ve nitelikli öğretmen yetiştirilmesi esasına dayanmaktaydı. Kongre kararlarını hayata geçirmek maksadı ile ilk olarak 1923 yılında, Milli Eğitim Bakanı İsmail Safa Özler, dünyanın en önemli eğitimcilerinden biri olarak benimsenen Amerika Kolombiya Üniversitesi Profesörlerinden John Dewey'i eğitim sistemimizi incelemesi için Türkiye'ye davet etmiştir. Hükümetin davetlisi olarak Türkiye'ye gelen John Dewey Türkiye nüfusunun kırsal sahada toplanmasından da hareketle özetle, 1924 raporunda, köyler için ayrı

\footnotetext{
${ }^{4}$ Geleneksel nakilci tarihçilik ile analitik tarihçiliğin özellikleri hakkında bkz. Peter Burke, The French Historical Revolution: The Annels School 1929-1989, Polity Press, Cambridge 1990.

${ }^{5}$ DPT, Atatürk'ün Doğumunun 100. Ylldönümünde Rakamlarla ve Fotoğraflarla Kalkınan Türkiye, DPT Yay., Ankara 1981, s.

${ }^{6}$ A. Afetinan, İzmir İktisat Kongresi 17 Şubat- 4 Mart 1923, TTK Yay., Ankara 1989, s. 21-22.
} 
köy öğretmen okullarının gerektiğine ve köy hayatına uygun eğitim ve köy öğretmeni yetiştirme konusuna yer vermiştir. Bu doğrultuda, yeni tip muallim mekteplerinin kurulması hakkındaki tavsiyeleriyle bu mesele üzerinde durulmasına işaret etmiştir. John Dewey, köy okullarında köylülerin çiftçilerin ihtiyaçlarını esas alan ve bunlara önem verilmesi gerektiğini, bunları hesaba katmaksızın kurulabilecek bir Türk milli eğitim sisteminin ülkenin ihtiyaçları ile örtüştürülemeyeceği vurgulanmıştır. Özetle Dewey, öğretmen yetiştirecek köy öğretmen okulları açılmasını bir zorunluluk olarak telakki etmiştir ${ }^{7}$.

Cumhuriyet yönetimi öğretmenliği bir meslek haline getirmek için yasal tedbirler almıştır. 13 Mart 1924'te Orta Tedrisat Muallimleri Kanunu ve 22 Mart 1926 tarihli Maarif Teşkilâtına Dair Kanunu'nda öğretmenlik mesleği tanımlanmıştı. İlkokul öğretmeni yetiştirilmesi konusu da ayrı bir problem olmuştur ${ }^{8}$. Diğer taraftan, 1927 yılı içerisinde yapılan tahminlere göre milli gelirin \% 67'si tarımdan temin edilmekteydi. Tarım üretimi, ülkenin sosyal ve politik şartları sebebiyle oldukça düşüktü. Tarım arazisinin bir kısmı büyük arazi sahiplerinin elindeydi. Ancak çoğunluğu, küçük çiftçiler oluşturmaktaydı. Bu iki çiftçi grubu da ağır vergiler nedeniyle son derece fakir kalmıştı. Ayrıca ülkede orta ve büyük sanayi teşekküllerinin yetersizliği nedeniyle sanayi ürünleri dışarıdan temin edilmekteydi. ${ }^{9}$

İşaret edilen yetersizliklerden de hareketle köye yönelik öğretmen yetiştirme politikalarının 1926 ve 1936 yılları arasında yoğunlaştığı görülmektedir. Türkiye'de 1926 yılından başlamak üzere, Mustafa Necati Bey'in başlatmış olduğu köy öğretmeni yetiştirme ve köy muallim mektepleri açma girişimlerine paralel olarak, bu görüşleri destekleyen yazılar çeşitli yayın organlarında kaleme alınmış olsa da bu süreç Mustafa Necati Bey'in ölümü ile sona ermiştir. 1932 yılı sonunda, Dr. Reşid Galip'in Maarif Vekili olmasıyla başlayan köycülük hareketiyle birlikte, köy öğretmeni yetiştirme düşüncesi bazı eğitimci ve yazarlar tarafından gündemde tutulmaya çalışılmıştır ${ }^{10}$. Türkiye'de kırsalın canlandırılmasına yönelik farklı bir yaklaşımı

7 Şehir ilk öğretmen okulları olarak da adlandırılan klasik öğretmen okullarından mezun olanların genellikle köylerde görev yapmak istememeleri, burada görev yapanların ise, şehir yaşamından çok farklı olan köy şartlarına uyum sağlayamamaları Cumhuriyet idaresini bu tablo ile karşı karşıya bırakmıştır. Bkz. MEB, The John Dewey Report, MEB Yayınları, Ankara 1960, s. 14-17.

${ }^{8}$ Dönemin önemli bir gelişmesi 20 Nisan 1920 tarihinde Teşkilat-1 Esasiyye Kanunun kabulü ile bu kanunun 87. Maddesinde yer verilen "İlköğretim bütün Türkler için zorunlu ve devlet okullarında parasızdır." denilerek, ilköğretim zorunlu hale getirilmiştir. Cumhuriyetin ilk hükümeti döneminde, öğretmen yetiştirme politikasında iki konunun üzerinde önemle durulmuştur. Bunlardan ilki, yetişecek öğretmenin köyü kurtaracak nitelikte olması, ikincisi ise yeterli sayıda olmasıdır. Donanım bakımından eksik okulların birleştirilip yeniden öğretime sokulması bu amaca uygun çalışıldığını göstermektedir. Bkz. Nurdan Kalaycı, Cumhuriyet Döneminde İlköğretim Hükümet Programları ve Uygulamalar, Milli Eğitim Gençlik ve Spor Bakanlığı Yayınları: 762, İstanbul 1968, s. 23.; İllerde bulunan Erkek ve Kız Muallim Mektepleri il özel idareleri elinde gelişemedikleri için 1 Eylül 1923'te Maarif Vekaleti'ne bağlanıp genel bütçe içerisine alınmıştır. $\mathrm{Bu}$ şekilde gündemde tutulan mesele, Darülfünûn müderrislerinden Ali Haydar (Taner)'ın 1924 sonlarında verdiği bir konferansta, köylere öğretmen yetiştirmek üzere üç yıllık Köy Muallim Mektepleri'nin kurulmasını teklif etmesiyle ve 1 Mayıs 1924 tarihinde Konya'da toplanan Maarif Kongresi Müfettişleri Kongresi'nde konunun tartışılmasıyla, Cumhuriyet döneminin ilk yıllarında da gündemi işgal etmiştir İlköğretim kademesindeki bu çalışmaların amacı, Mustafa Kemal Atatürk'ün hedefini çizdiği "Modern Türk Toplumunu" idealini gerçekleştirmek için kalkınmada gerekli eğitilmiş insan gücünü yetiştirip bir üst öğrenime hazır hale getirmektir. Anlaşılacağ1 üzere, 1924-1926 öğretime yönelik çıkarılmış olan yasalar; milli, laik, modern ve demokratik bir okul yaratmayı öngörmüştür. Bkz. (Cemil Öztürk, Atatürk Devri Öğretmen Yetiştirme Politikası, TTK Yay, Ankara 1996, s. 127.)

${ }^{9}$ Roger R. Trask, "The United States and Turkish Nationalism: Investments and Tecnical Aid during the Atatürk Era", The Business History Review, Vol. 38, No. 1, (Spring, 1964), p. 67.

${ }^{10} \mathrm{Bu}$ çalışmalardan en önemlisi Bakanlıkta Ziraat ve Sağlık Bakanlıklarının temsilcilerinin de bulunduğu bir Köy İşleri Komisyonu'nun kurulmasıdır. Komisyon hazırladığı raporda, ziraat eğitimine dayanarak köy kalkınması merkezi fikri etrafında, devletin köyde adamı olacak, köyün maddi ve manevi hayatını değiştirecek yeni bir köy öğretmeni tipinin yetiştirilmesi gereğinin belirtildiği bir rapor hazırlar. Ancak Reşit Galip'in kısa süren bakanlığ sırasında etkili bir girişimde bulunulamamış, sadece Ankara, İzmir Bursa ve Adana'da köy öğretmenlerini 
ortaya koyan isimlerden bir diğeri de Nusret Kemal Köymen ${ }^{11}$ olmuştur. Köymen'in temel hedefi, köylülerin yaşam biçimlerinden ödün vermeyecek önlemleri almak suretle, kırsaldaki koşulların düzeltilmesiydi. Köymen'e göre; Cumhuriyetin ilk yıllarında kasaba ve şehirlere köylülerin göç etmelerinin en önemli nedenleri, köylülerin sadece bir ürüne bel bağlamaları, kırsalda pratik sağlık hizmetlerinin ve çoğu köyün herhangi bir okuldan yoksun olmasıydı. Bu nedenle, köydeki genç nüfus kendilerini geliştirmek amacıyla kentlere göç etmek zorunda kalmıştır. Türkiye'nin köy nüfusunu koruması için Köymen'in önerisi, bilimsel tarım metotlarını köylere tanıtmaktı. Ayrıca, küçük üretim birimlerini ve temel sosyal hizmetleri sağlamak için toplum kuruluşları ile birlikte serbest girişim (özel teşebbüs) yoluyla geliştirilebilirdi. Bu dönüşüm için gerekli olan sosyal bir iş merkezi gibi fonksiyona sahip olacak kurum yeni bir tür halk okulu idi. Bu kurumlar köy çocuklarına batı teknolojisi tanitılacak ve uygulama dersleri yetişkinlere öğretilecekti ${ }^{12}$. Köylere eğitimin götürülmesinde ekonomik kaynak sıkıntısının yanında asıl sıkıntı öğretmen yetersizliğidir. II. Meşrutiyetten itibaren köye özel öğretmen yetiştirme gerekliliği düşüncesi olmuştur. Köye öğretmen yetiştirmek fikri ihtiyaçtan kaynaklanan bir durumu ifade etmektedir.

Diğer yandan, CHP'nin meclis grup toplantılarında ve 1935 yılı IV. Büyük Kurultayı'nda mesele ele alınmıştır. Bu kurultayda hazırlanan programda köyde yaşayan çocukların köy hayatının ihtiyaçları doğrultusunda eğitilmeleri gereği üzerinde durulmuştur ${ }^{13}$. Dicle Köy Enstitüsü'nün kurucu müdürlüğünü üstlenmiş olan Nazif Evren, illerin bütçelerine Milli Eğitim için konan ödenekten öğretmen maaşlarının bile ödenemez durumda olduğu döneme vurgu yapmak suretiyle, ülkenin mali ve eğitim durumunu gözler önüne şu sözleriyle sermiştir: “Ístatistiklere göre 1934'teki Milli Ë̆itim Bakanlığı bütçesi 9.500.000 TL kadardı. Genel bütçe ise 200 milyon liradır. 1935'te genel bütçe 250.5 milyon Milli Eğitim Bakanlı̆̆ı'na ayrılan ödenek 10.690.00 lira, 1936'da genel bütçe 260 küsür milyon, Milli Eğitim Bakanlı̆̆l'nın payı 10.415.000 liradır. Bu Bütçe ile yeni okul binaları yapmak, okul araçları almak ve orta dereceli okul öğretmenlerinin maaşlarını vermek olanak dişlydl. Ancak mevcut ekonomik tedbirler ile idare etmek yoluna gidilmesi gerekli idi. Bu ortam içinde de okulların yetiştirdiği kişiler; geçimi maaşa dayal, başka iş yeteneği olmayan kişilerdi. Şehirlerde açılan orta dereceli okullar, üretime dayalı ĕgitim yapamamaktaydı. Öğretmen okullarında

amaçlanan esaslar doğrultusunda yetiştirmek üzere, 40 günlük kurslar açılmıştır. Bkz. Osman Kafadar, Türk Eğitim Düşüncesinde Batılılaşma, Vadi Yay., Ankara 1997, s. 294.; Bu sırada köye yönelik öğretmen yetiştirme anlayışı doğrultusunda, bu yıllarda basında çıkan yazılarda H. Reşit Öymen, K. Nami Duru, B. Ziya Egemen, Yunus Nadi ve H. Fikret Kanad gibi yazar ve eğitimciler tarafından da tartışılmıştır. Öğretmen ihtiyacını karşılamak üzere bu okulların öğrenci mevcudu ve öğretim niteliği yükseltilmeye çalışılmış fakat Köy Enstitüleri kuruluncaya kadar ilk öğretmen okulları ile yeterli sayıda öğretmen yetiştirilmesi mümkün olmamıştır. Yahya Akyüz, Türk Ĕgitim Tarihi, Alfa Basım Dağıtım, Ankara 2001, s. 344-345.

11 İstanbul doğumlu olan Köymen 1918 yılında Osmanlı'nın mağlubiyetine yine burada şahit olmuştur. Robert Koleji ticari bölümünden mezun olduktan sonra, Köymen Wisconsin Üniversitesi'ne başvurdu ve burada kırsal sosyoloji öğrenimi görmüştür. Köymen, ülkesinin askeri yenilgisine kırsal Anadolu'nun geri kalmışlığının neden olduğunu da düşünmektedir. Bilimden yoksun tarımın ve ilkel metotların, milletin gücünü zayıflattığına inanmıştır. Yurtdış1 öğreniminden döndükten sonra, Köymen birçok genç eğitimciyi etkilediği Türkiye'de, birçok öğretmen okullarında birkaç yıl için eğitim sosyolojisi dersleri vermiştir. Köymen, kırsalın canlandırılması konusunda Türk hükümetinin ilk danışmanlarından birisi olduğu için, görüşlerini savunduğu ve açıkladığı yirmiden fazla kitabı Milli Eğitim Bakanlığı tarafından sıklıkla yayınlanmıştır. Frank A. Stone, Rural Revitalization and the Village Institutes in Turkey: Sponsors and Critics, Comparative Education Review, Vol. 18, No. 3 (Oct., 1974), s. 418.; Köymen'in kitapları için bkz. Bkz. Nusret Köymen, Büyük Aydınlı̆̆a Doğru, Nebioglu Yayınevi, İstanbul 1960; ilk baskıs1 1952'de Demokrasiyi Kurtaralım şeklinde olmuştur. Ayrıca, Nusret Köymen, Halk Egitimi Rehberi, Maarif Basımevi, Ankara, 1956; ve Nusret Köymen, Köycülük Bilimi, Güven Basımevi, İstanbul 1964.

${ }^{12}$ Frank A. Stone, Rural Revitalization and the Village Institutes in Turkey: Sponsors and Critics, Comparative Education Review, Vol. 18, No. 3 (Oct., 1974), s. 421-422.

${ }^{13}$ İsmail Hakk1 Tonguç, Canlandırılacak Köy, İstanbul 1939, s. 170. 
ögretmenlerimiz köylere gitmemizi öneriyorlardı. Ama köyde yapacağımız işler hakkında bir yöntem önerisi veremiyorlardl. Köy ve köylü salt konu olarak ele alınmıştı. Halkevlerinde köycülük kolları vardı. Bir kısım gençler, köylere gidip nutuklar çekiyorlardl, ama köyün ve köylünün kalkınmasını etkileyemiyorlardı. ",14

Mevlüt Kaplan enstitülerin kurulmasından evvelki mevcut duruma dair;"1935 yılında halkımızın \%82 'si köylerde, otuyordu. Erkeklerin sadece \%17'si, kadınların \%4.2'si okumayazma biliyordu. Temel eğitim çağında olan 15 milyon köy çocuğundan ancak 275 'bini okula gidebiliyordu...Büyük Eğitimci İsmail Hakkı Tonguç, o dönemde tek kurtarıcı olarak görülmüş, Illköğretim Genel Müdürü görevine getirilmiştir. Avrupa ülkelerinin eğitimini yakından tanıyan Tonguç bu kez de Anadolu'ya çıkmıs, 61 il, 305 ilçe ve 9150 köyü inceleyerek Köy Enstitülerine giden yolu göstermiş" ifadelerine yer vermiştir ${ }^{15}$.

Netice itibariyle, 1939 tarihli 3704 sayılı Köy Eğitmen kurslarıyla Köy Öğretmen okullarının İdaresi'ne Dair Kanun aracılığı ile tamamen Maarif Vekaleti'ne bağlanarak teşkilatlandırılan ve beş yıllık eğitim ve öğrenim süreli Köy Enstitüleri kurulmuştur. Ayrıca sistemin adeta can damarı olan "Yüksek Köy Enstitüsü" 1942 yılında, "sağllk kollarl" ise 1943 'te açılmıştır. İlk mezunlar da 1943 yılından itibaren köylerde çalışmaya başlamışlardır. 1940'lı y1llarda Türkiye'de yaşama geçirilen bu model sistemin, yarattığg etki ile uluslararası düzeyde de büyük ilgi çektiği görülen Köy Enstitüleri hukukî kimliğini TBMM’ye sunulması ile başlayan bir sürecin ardından kazanacaktır.

\section{Tanıkların Gözüyle Enstitülerin Açılışları Üzerine Notlar}

Başbakanlık tarafından 19 Mart 1940 gün ve 6/1194 sayılı bir tezkere ile Köy Enstitüleri kurulması hakkındaki kanun tasarısı TBMM Başkanlığı'na sunulmuştur. Kanun layihasının gerekçeleri şu alt başl1klarla izah edilmiştir: Illk tahsilin bu günkü durumu ve köy, müstahsil nüfus, köylünün okutulması ve daha iyi bir müstahsil durumuna getirilmesi, nüfusun dağllış tarzı ve ilk öğretim, köy eğitmenleri, köy ögretmenleri, köy enstitüleri, köy enstitüsü kanun projesi hükümlerinin mucip sebepleri ${ }^{16}$. TBMM üye sayısı 429 olduğu dönemde ilgili kanunun oylanması sonunda kabul oyu kullanan milletvekili sayıs1 278 olup ret oyu kullanan milletvekili olmamıştır. Oylamaya katılmayan milletvekili sayısı 148 ve münhaller sayısı ise 3 'tür ${ }^{17}$.

Kanunun kabul edilmesinden sonra Maarif Vekili sıfatıyla Hasan Ali Yücel şu konuşmayı yapmıştır: "Sayın arkadaşlarım, bizim hazırladığımız, encümenlerin üstünde çalıştı̆̆ı bu kanun layihasını şu anda kabul etmiş bulunuyorsunuz. Bu kanunun memleketimizin istikbali, halkımızın maarif ihtiyacı ve köylümüzün kalkınması bakımından haiz olduğu ehemmiyet, tasvibinizle bir kere daha ve en esaslı surette tahakkuk etmiştir. Bunu görmekle büyük bir bahtiyarlı duyuyorum ve şahsen, uzun ylllar kalbimde sakladı̆̆ım bir idealin tahakkukuna şahit oluyorum. Onun için yüksek heyetinize bütün samimiyetimle, bütün yüreğimle bu tarihî

\footnotetext{
${ }^{14}$ Nazif Evren, Köy Enstitüleri Neydi, Ne Değildi, Güldikeni Yay., Ankara 1998, s. 25-26.

${ }^{15}$ Mevlüt Kaplan, Köy Enstitüleri ve İş Eğitimi, Foça Belediyesi ve TMMOB Ziraat Mühendisleri, İzmir 1995, s. 67.

${ }^{16}$ TBMM Zabıt Ceridesi, Devre: 6, C.10, s. 1-6.; Mahmut Goloğlu, Millî Şef Dönemi (1939-1945), Kalite Matbaas1, Ankara 1974, s. 65-69; Maarif Encümeni 26 Mart 1940 tarihînde, Ziraat Encümeni 29 Mart 1940 tarihînde, Dahiliye Encümeni 3 Nisan 1940 tarihînde ve Bütçe Encümeni Mazbatasını 13 Nisan 1940 tarihînde Meclis Başkanlığına sunmuştur. (Maarif Encümeni Mazbatası Esas No:1/339, Karar No:3, Ziraat Encümeni Mazbatas1 Esas No:1/339, Karar No:9, Dahiliye Encümeni Mazbatası Esas No:1/339, Karar No:35, Bütçe Encümeni Mazbatası Esas No:1/339, Karar No:35). (Zabit Ceridesi C.10,1940: Ek Mazbatalar, 7-12). Köy enstitüleri teşkili hakkında kanun lâyihası ve Maarif, Ziraat, Dahiliye ve Bütçe encümenleri mazbataları (1/339 sayı ile) Meclis'in 15 Nisan 1940 tarihli toplantısında gündeme alınmış ve 17 Nisan 1940 tarihînde görüşülmeye başlanmıştır. Bkz. TBMM Zabit Ceridesi, Devre: 6, C.10, s. 62.

${ }^{17}$ TBMM Zabut Ceridesi, Devre: 6, C.10, s. 35.
} 
anda en derin teşekkürlerimi arz ederim”. ${ }^{18}$ TBMM'de kabul edilen Köy Enstitüleri Kanunu Köy Enstitülerini İlk Öğretmen okulları ile birleştiren 6234 sayılı kanun çıkarılıncaya kadar uygulanmıştır. $^{19}$

İstanbul Milletvekili Kâzım Karabekir ise, kanuna ilişkin farklı değerlendirmelerde bulunmuştur. Ona göre, "Kanun lâyihası büyük bir ihtiyacı karşıladı̆̆ından hakikaten her türlü şükrana lâyıktır... Bir kere bu müesseseler kurulurken harp halinde dahi bir istihsal merkezi olarak faaliyette bulunması düşünülmeli ve harpte istihsal kudretlerini arttıracak tedbirler almalıdır..." Kâzım Karabekir, üç madde altında nelere önem verilmesi gerektiğini açıklamıştır. Birincisi lüzumsuz masraflara boğulmamaktır. Onun için çok tasarruflu hareket edilmelidir. Köylerin hayat şartlarını daima göz önünde bulundurarak bu kuruluşu kurmak lâzımdır. İkincisi büyük bir titizlikle hedefe yürünmeliydi, yani bilgili iş adamları yetiştirmek gerekliydi. Enstitülerin kuruluşlarında ve idamesinde bu noktayı gözden kaçırmamak lâzımdı. ${ }^{20}$ Fakat Kâzım Karabekir kanunda bir noktayı mahzurlu görmektedir. Bu kanunun üçüncü maddesidir: “...köy enstitülerini yalnız köy ilk okullarını bitiren çocuklara hasrediliyor. Şehir ve kasaba çocuklarının köylerle temasını kesiyor. Halbuki dünyanın her tarafinda bu teması çoğaltmak için yeni yeni tedbirler alındığını görüyoruz. Biz şehir ve köy çocuklarına böyle birbirleriyle kaynaştıracak yerde bir safiyeti fikriye ile ayırırsak, sonra acaba bu köylere başka taraflardan yapılacak telkinlerle günün birinde biz bu şehirlilerin karşısında başka fikirlerle onları mücehhez bulmaz miyız? Onun için bendenize öyle geliyor ki, şehir çocuklarını köylere götürmek için diğer devletlerin yaptığı gibi daha bazı tedbirler almalıyız. ${ }^{, 21}$. Buna karşılık Bakan Yücel, bu düşüncelerin aksine; enstitülerin kurulmasında güdülen amacın bu ayrımı ortadan kaldırmak olduğunu ifade etmiştir.

$\mathrm{Bu}$ süreçte, Köy Enstitülerinin kurulacağ durulmuştur. Enstitülerin kuruluş süreçlerine dair Pakize Türkoğlu şu değerlendirmelere yer vermektedir: "Enstitü müdürleri Ankara'dan görev yerlerine uğurlanırken onlara bildirilmişti. Yapacakları öncelikli işlerden biri kuruluş yerlerinin alım satımını hemen bitirip, topoğrafya haritasını çizdirerek bakanlı̆̆a göndermekti. Gecikenlere yeniden yazılmıştı. Yeni kuruluşların yapıları, karanlık koridorlarında öğrencilerin hayal gibi dolaştığı eski tip yatılı okullara benzemeyecekti. Öğrencinin kalacă̆l yerler, ellişer ya da en çok yüzer kişilik kümeler için, etüt ve yemek odasını, mutfă̆ını, küme ögretmeninin konutunu da içine alan birimler olarak düşünülmüsstü...Ancak yörenin özelliğine göre her bölgedeki Enstitünün gereksinimleri

${ }^{18}$ TBMM Zabit Ceridesi, Devre: 6, C.10, s. 92.

${ }^{19}$ İsmet Türkmen, "Rural Revitalization and The Village Institutes Experience in Turkey (1940-1954)", European Journal of Multidisciplinary Studies, (September-Decembery 2017), V. 6, Nr. 1, ss. 17-22.

20 Kâzım Karabekir, “...Çünkü bugün köylerde dahi teessüs etmiş ve ayni maksatlarl ifade edilmiş öyle mekteplerimiz vardır ki köyden alıp da yetiştirdiği çocuğu o köyde tutamıyor. Çünkü kazması, küreği vardır. Fakat depolarda daha ziyade istirahat halindedir. Onun için bu noktayı arz ettiğim gibi büyük bir dikkat sarfi lâzımdır. Üçüncüsü sağlam vücud ve sağlam seciye hususlarına çok dikkat edilmek lâzımdır..." diyerek uzun uzun söz konusu başlıklar hakkında açıklamalarda bulunmuştur. TBMM Zabıt Ceridesi, Devre: 6, C.10, s. 72.

${ }^{21}$ TBMM Zabit Ceridesi, Devre: 6, C.10, s. 73-74. Bu hususta ise tamamen farklı bir bakıș açısından hareketle Can Dündar'ın; "Karabekir Paşa, bu enstitülerin zaten bir sorun olan köy-şehir uçurumunu hepten derinleştireceğini ve bu iki kesim arasında bir ayrım yaratacağını öne sürdü." (Dündar, Köy Enstitüleri, s. 23-24) ifadeleri tarihî bir yanılgının doğmasına sebep olmuştur. Bu durum, TBMM Zabıt Ceridelerinden araştırıldığında Kâzım Karabekir'e yönelik haksız bir suçlama içinde olunduğuna ve bunun özellikle gelecek nesiller üzerinde Karabekir Paşa'ya yönelik enstitüler konusunda önyargılara neden olacağı açıktır. Anlaşılacağı üzere, Kazım Karabekir, diğer eleştirilerden çok farklı bir amaç ve şekille mevcut yapının işlevselliğinden endişe duymayıp, uygulamanın toplumda Osmanlı Devleti'ndekine benzer kurumsal ikililiklere yol açacağı endişesi ile, bu enstitülerin o dönemde bir sorun alanı olan köy-şehir uçurumunu derinleştirebileceği düşüncesini şu şekilde ifade etmiştir. TBMM Zabıt Ceridesi, Devre: 6, C.10, s. 92; Karabekir son olarak enstitü kelimesi üzerinde durarak enstitü yerine bu okullara "hayat mektebi" veya "hayat kaynağı" gibi daha anlaşılır, köylüler ve çocuklar üzerinde daha tesir bırakacak bir isim vermenin daha uygun olacağını belirtmiş̧tir. Bkz. TBMM Zabıt Ceridesi, Devre: 6, C.10, s. 72-73. 
değişikti. Her enstitünün geleceğe yönelik durum planı ve yapıların projesi bir an önce tamamlanmalıydl. Türkiye'de bugün kentleşmede bile plan proje aranmazken, o dönemde, bu kurumların plana, projeye bağlanması için mimarlar arasında yurt çapında bir yarışma açılmış̧ı. Yarışmaya katılacak mimarlar için projesini yapmak istediği Enstitüye gidip orada en az bir hafta kalarak inceleme yapması koşulu koyulmuştu. Yöreyi, kuruluş yerini, yöresel mimari ve yapı tekniklerini görecek, kurulmakta olan Enstitülerin çalışmalarını yakından izleyerek projesinde bunlardan yararlanacaktı. Yarışma kurulunda doktor, genel müdür, Enstitü müdürü, tarım uzmanı vb. uzmanlar bulunuyordu...,22

Enstitülerin açılmasını takip eden ilk yıllarda bazı enstitülere öğrenci bulunması sırasında karşılaşılan sorunlara ilişkin Fay Kirby eserinde öğrenci alımlarında baskı yapıldığına dair iddialara şu ifadelere yer vermek suretiyle işaret etmiştir: "Alınan çocuklardan gelen bilgiler bask kullanıldiğını kanıtlamıyor, hatta Köy Enstitülerini kötülemenin moda olduğu dönemde bile, hiçbiri böyle bir sav ortaya atmamıştır. Tersine üstün olan eğilim, Enstitülere gelenlerin kendi istekleriyle ve toplumsal basklya karşı geldiklerini açılklama yönündedir. ",23

\section{Enstitülere Yönelik Suçlamalar-Tepkiler}

Enstitülere yönelik olarak 1945 sonrasında yoğunluk kazanan eleştirilerin başlıca kaynaklardan beslendiği söylenebilir. Enstitülerin bazı kurucularından, enstitü müdürlerinden ve öğrencilerden gelen eleştiriler, tutucu çevrelerin yaklaşımı ve son olarak solcu çevrelerden gelen eleştiriler bu kaynakların menşeini teşkil etmektedir ${ }^{24}$.

1943 yılında toplanan 2. Eğitim Şûras1 günlerinde, Köy Enstitüleri'nin aleyhine propaganda ve eleştiriler ortaya çıkmaya başlamıştır. 1946 seçimleri öncesinde ise muhalefet, enstitülere yönelik aleyteki propagandalarını arttırmış ve buna daha geniş çevreleri de ortak etmeyi başarmıştır. Muhalefetin giderek enstitüler üzerinde yoğunlaşan baskılarını Dicle Köy Enstitüsü Müdürü Nazif Evren şu ifadelerle nakletmektedir: "Karalamalar gırla gidiyordu. Köylerdeki okul yapımı gevşedi. Köy Enstitüsü müdürleri ve bakanlıktaki bu kurumların başları yerlerinden, görevlerinden alınmaya başladılar. Büyük Millet Meclisi, havasını bu propaganda doğrultusunda yöneltti. Bakanlığın tutumu değiști. Yücel, Tonguç, Ferit Oğuz Bayır işbaşından uzaklaştırıldılar. "25 Enstitüler üzerinde 1946 y1lı başlarından itibaren yoğunluğunu arttıran eleştiriler giderek suçlamalara dönüşmüştür. ${ }^{26}$.

\subsection{Enstitülerin Halkçılık İlkesine Ters Düşsüğü İddiaları}

Kuruluşlarından itibaren, eleştiri sahiplerince enstitülere yalnızca köy çocuklarının alınması, mezunlarının da yine köylerde görevlendirilmesi, toplumda bir köylü-kentli ayrımı yani sınıf farklılı̆g 1 doğuracağ1 ve bu bölünmenin anayasaya girmiş olan halkçılık ilkesine ters düşeceği iddia edilmiştir. Bununla beraber okul, işlik, öğretmenevi yapımında ve çocuklarını okula

\footnotetext{
${ }^{22}$ Pakize Türkoğlu, Tonguç ve Enstitüleri, Türkiye İş Bankası Kültür Yay., 3. Baskı, İstanbul 2007, s. 202-203.

${ }^{23}$ Fay Kirby, Türkiye'de Köy Enstitüleri, (Çeviren: Niyazi Berkes), 4. Bask1, Tarihçi Kitabevi, İstanbul 2012, s. 293.

${ }^{24}$ Yahya Kemal Kaya, Insan Yetiştirme Düzenimiz, 4. Bask1, Ankara 1984, s. 305.

${ }^{25}$ Nazif Evren, Poyraz Köyünden Köy Enstitüleri’ne, Güldikeni Yay., 2. Bask1, Ankara 1997, s. 90-91.

${ }^{26}$ Değişik nedenlerden kaynaklanan bu eleştiri ve suçlamalar üzerine 25 Ocak 1946 tarihînde İsmail Hakkı Tonguç içinde Pamukpınar Köy Enstitüsü Müdürü Şinasi Tamer'in de bulunduğu on Köy Enstitüsü müdüründen sırasıyla; beş öğrenciden kendi el yazıları ile serbest tahrir vazifelerini kaleme almalarını üçüncü ve dördüncü sınıfları öğrencilerinin okudukları kitapların adlarını gösteren bir çizelgeyi, bir öğretmenin bir haftalık programını, yakın köylerde çalışan eğitmenlerden üç okulun öğrencilerine ait kendi el yazılarını gösterir bir parçalık yazı, gezici başöğretmenin bizzat yazacağı ve bir haftalık çalışmalarını anlatan üç sayfalık yazı, mezunlardan gelen ve onların ülküye bağl1lıklarını ve çalışma heyecanlarını anlatan mektuplar, enstitü müdürleri mezunlara hitaben yazılmış mektup örnekleri talep edilmiştir. Bkz. İsmail Hakkı Tonguç, Mektuplarla Köy Enstitüsü Yılları (1935-1946), (Yay. Haz. Engin Tonguç), 2. Baskı, İstanbul 1990, s. 205-207.
} 
göndermede köylülere getirilen yükümlülüklerin, son derece ağır olduğu, özellikle yurdun ulaşımı güç olan bölgelerinde tek tip okul binası projesinin uygulanmasının yapım giderlerini daha da arttırdığı ve bu yükümlülüklerin yine anayasanın eşitlik ilkesine aykırı olduğu iddiaları enstitüleri yıpratmaya yönelik propaganda malzemesi olarak kullanılmıştır ${ }^{27}$.

Eleştiri sahiplerince enstitülerde aşırı solcu, hatta komünist ideolojiyi yansıtan bir eğitim ve öğretim yapıldığını, öğrencilerin okul yapımlarında, tarım ve teknik uygulamalarında, temizlik ve bakım işlerinde çalıştırılmalarının Sovyet Rusya'yı ve komünist rejimlerini anımsattığını ve bu tür eğitimin milliyetçilik ilkesiyle çelişeceğini öne sürmüşlerdi. Bu çevrelerce, enstitülerin yönetim kadrosu genelde solcu, Marksist tanınan kişilerce doldurulduğu iddia edilmiştir. Enstitülerin yeterince milliyetçi olmadığına ve bazı çevrelerin programın milliyetçilik taşımadığı eleştirisine Türkoğlu; "Oysa, programın getirdiği gerçekçi içerik ve ilkeler bu anlamı içinde taşıyordu. Ülkeyi bayındırlaşmayı, köyleri canlandırmayı lafla değil, 'iş' olarak amaçlayan, tarımı, tekniği, güzel sanatları yaşamın vazgeçilmez bir parçası olarak gören bir programda fazla söze gerek yoktu..." şeklinde cevap vermektedir ${ }^{28}$.

Özellikle enstitülerin sınıfsal bir nitelik taşıdığı iddiası, Eskişehir Milletvekili Emin Sazak tarafından Meclis gündemine taşınmıștır. Sazak'a göre enstitü mezunlarına verilen yetkiler çok fazladır Milli Eğitim Bakanı Hasan Âli Yücel 23 Mayıs 1945 tarihînde Meclis’te Bakanlığın bütçe görüşmeleri sırasında Sazak'ın itirazlarını yanıtlarken şu tespitlerine yer vermiştir: "Emin Sazak, Köy Enstitüsü mezunlarının kendilerini birer Atatürk zannettiklerini ve hatta daha salahiyetli hissettiklerini söylüyor. Biz, arkadaşlar, köy enstitüsündeki bu Türk çocuklarını, sizin kabul ettiğiniz kanunlarda yazll ne vazifeler varsa onlarl yapmak üzere yetişstiriyoruz. Bu çocukların birer Atatürk olması herhalde temenniye değer bir şeydir. Amma Atatürk olmak güçtür. Biz onları Atatürk'ün parçaları olmak üzere yetiştiriyoruz...Çünkü ilköğretim davası milletlerin rüşünü ispat etme davasıdır. Illköğretim davası feodal sistemle kendisini idare etmek isteyenlerin samimi olarak istemeyeceği bir davadır ...."

Eğitim yoluyla canlandırılması düşünülen köyde yaşayan nüfusu Engin Tonguç, “bilinçlenmiş köylü aydın”lar olarak tanımlamaktadır. Yeni tip öğretmenler aracılığıyla sınıf şuuru uyandırmanın en uygun sosyal tabanı olarak değerlendiren şu sözleri oldukça dikkat çekicidir: "Köy Enstitüleri sistemi başlı başına ne bir okuma-yazma kampanyası, ne bir köy kalkınması sorunu, ne bir öğretmen yetiş̧irme çabası, ne bir okul yapımı girişimi idi. Temel amacı bakımından, tarihsel koşulların hazırladığı bir olanaktan yararlanarak iktidara katılıp elde edilen yürütme gücü ile emekçi sinıfları bilinçlendirmek ve devrimsel süreci hızlandırmak için girişilmiş bir devrim stratejisi ve taktiği idi "30

\subsection{Enstitülerde Karma Eğitim}

Enstitülere yönelik siyasî mahiyetteki eleştirilerin yanında sosyal açıdan da yoğunluk taşıyan tepkiler mevcuttur. Yatılı olan enstitülerde uygulanan karma öğretimin Türk aile ve

\footnotetext{
${ }^{27}$ İsmail Hakkı Tonguç’un 4 Aralık 1944 tarihînde Köy Enstitüleri’nin müdürlerine hitaben kaleme aldığı mektupta enstitülerde öğrencilere yüklenen sorumlulukların doğru algılanmasının sağlanmasına ilişkin değerlendirmeleri dikkat çekmektedir: "Işsbölümüne göre türlü işlere dağllacak kümelere, yapacakları işin önemi, memlekete, millete ve onların şahıslarına temin edici faydalar anlatılarak iş gördürülür. Öğrencilere angarya şeklinde, manası anlaşılmayan işlere bu kuramlarda, asla yer verilmeyecektir. Bir enstitüde işlerin soysuzlaştı̆̆ı görülürse bundan birinci derecede öğretmenler mesul tutulacaklardir. Her çocuk ögrretim programında tespit olunan şekillere göre kültür, ziraat ve sanat çalışmalarına mutlaka katılacaktır. Belli çocukları yalnız terzilik, şoför muavinliği, davar çobanlı̆̆l, tuğlacılık gibi belli işlerde uzun müddet çalıştırmak yasaktır.” Bkz. Tonguç, Mektuplarla Köy Enstitüsü Yilları (1935-1946), s. 89.

${ }^{28}$ Türkoğlu, Tonguç ve Enstitüleri, s. 211.

${ }^{29}$ TBMM Zabit Ceridesi, Devre: 7, Cilt: 17, s. 312)

${ }^{30}$ Tonguç, Devrim Açısından Köy Enstitüleri ve Tonguç, s. 270.
} 
ahlâk anlayışına uymadığı yönündeki eleştiriler buna örnektir. ${ }^{31}$ İsmail Hakkı Tonguç'un Öğretmen Okullarından ve Köy Enstitüleri'nden mezun öğrencilere hitaben kaleme aldığ mektupta toplumsal yaşamda kadının yerini şu ifadelerle özetlerken kadınının ve erkeğin eşit haklara sahip olması gerektiği şuurunun kazandırılması görevinin bu mezunların olduğu gerçeğine dikkat çekmektedir: "Kadını alabildiğine istismara, tazyike dayanan aile hayatının gelenekleri sizin yuvalarınızda kendilerine yüz ve yer bulmamalıdır. Kadın ve erkeğin eşit haklarlyla süslenen bir yuvanın sahibi olmalısınız. "32

Talip Apaydın, enstitülerde karma eğitimin kendileri üzerindeki etkisi üzerinde şu değerlendirmelere yer vermektedir: "Yatakhane, yüznumara hariç, her yerde onlarla beraberdik. Bir iki ay içinde doğallaştı. Alışıtı. Öbür arkadaşlarımız gibi gelmeye başladılar. Hatta onların yanında da daha dikkatli, daha uslu idik. Kötü konuşamıyorduk. İster istemez kendimizi topluyor, kibarlaşıyor, saygılı davranıyorduk. Bu konuda geliştirici, yüceltici sık sık konuşmalar dinliyorduk. Şu kadarını iyi anımsıyorum, kızlarla birlikte olduğumuz zamanlar, çalışırken, yemekte, teneffüslerde, her yerde daha bir özenli, daha iyi olmak zorunda kallyorduk. İki cinsin birbirini eğittiği, düzelttiğ gerçeğini ben kendi üstümde anlamışımdır. Fakat bu konuda görüssler ne kadar değişik, ne kadar farklı? Köy enstitülü kızlar için söylenenler onlara edilen iftiralar, halkoyunda belki en yıkıcı, en etkili propaganda oldu. Kızla erkeğin aynı okulda okuması, aynı elbiseyi giymesi, yan yana çalışması, birlikte yiyip içmesi, ele ele tutuşup halay, kafası hep kötüye çalışan softayı çıldırttı. Hayalinde olmadık sahneler kurdurttu ve halka zehir saçtırdl., 33

Kız ve erkek öğrencilerin aynı sınıflarda bulunmaları hakkında, özellikle siyasîler tarafından öne sürülen abartılı iddialar, çocukları enstitülerde öğrenim gören veya çocuklarını enstitülere göndermeyi düşünen köylü vatandaşlar arasında endişeye ve buralara yönelik önyargıların gelişmesine sebep olmuştur. Enstitüler, köy kızları için yurt çapında açılmış kapılardır ve yapılan eleştirilerin amacı Köy Enstitüleri'nin düzeninin bozulmasına zemin hazırlamaktır. Enstitülerdeki karma sistem; 1950-1951 eğitim-öğretim döneminde yapılan eleştiriler sonucu kız öğrenciler Kızılçullu ve Beşikdüzü Enstitülerinde toplanmış ve 21 enstitünün sadece iki tanesi kızlara ayrılmıştır. Bu durum enstitülerde az olan öğrenci sayısını da aza indirmekle kalmamış, esasında buralardan uzak olan bölgelerdeki köy çocuklarının öğrenim şanslarını tüketmiştir. Böylelikle enstitüleri bu türden karalama yoluna giden iddialardan beklenen sonuç sağlanmıştır ${ }^{34}$.

\subsection{Enstitülerin Kurulduğu Yer Meselesi}

Enstitülere yönelik eleştirilerin yoğunlaştığı diğer bir mesele ise, enstitülerin komünist karakterlerini gizleyebilmek maksadıyla ve köy çocuklarına kırsal sahada rahatça komünizmi aktarabilmek maksatlı kırsal alanlarda kurulmuş oldukları iddiasıdır ${ }^{35}$.

Enstitülerin köylerin kalkınmasında kültür ve eğitim merkezi olarak bir işlev yürütebilmesi amaçlı kırsal bölgelerde kurulduğu bir hakikattir. $\mathrm{Bu}$ açıdan, enstitülerin esas gayeleri sadece öğretmen yetiştirmek olmayıp, bu türden bir hizmetin kırsal kalkınma gibi çok daha mühim bir vazife de üstlenmiştir. Ayrıca bu müesseseler, ücra yerlerde kuruldukları iddialarının aksine

31 "Köy Enstitülerinde kızlarla erkekler hem de yatılı olarak birlikte dinci kesim bir erkek öğrencinin bir klz

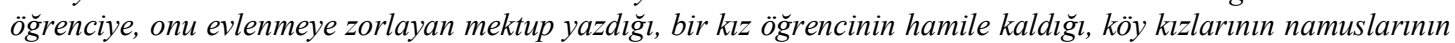
ayaklar altına alındığı gibi eleştiriler öne sürülmüştür.” Bkz. Aydoğan, Köy Eğitim Sistemi ve Köy Enstitüleri, s. 173.

${ }^{32}$ Tonguç, Mektuplarla Köy Enstitüsü Yillarl (1935-1946), s. 146.

${ }^{33}$ Apaydın, Köy Enstitüsü Yillarl, s. 90-91.

${ }^{34}$ Ş. Gediklioğlu, Türkiye'de Yaygın Eğitimden Çă̆daş Ĕgitime, Kadığlu Matbaası, Ankara 1991, s.289-290.

${ }^{35}$ Kaya, Insan Yetiştirme Düzenimiz, s. 306. 
ana yollar ve demiryollarına yakın yerlerde inşa edilmişlerdir. Pamukpınar Köy Enstitüsü örneğinde de görüleceği üzere, iletişim ve araç ulaşım kolaylıkları da dikkate alınarak, şehir ve kasabalardan sadece birkaç kilometre uzaklıktadırlar. Enstitü öğrenci ailelerine, yabancı misafirlere açık tutulmakla birlikte, öğrenciler hafta sonları ve tatillerde kasaba veya şehir merkezlerine ihtiyaçlarını karşılamak üzere serbest bırakılmışlardır ${ }^{36}$.

Esas itibariyle, enstitülerin yerleşme alanlarını bu şekilde eleştiriye tabi tutanlar, Enstitülerin yerlerini Öğretmen Okullarına bıraktığı esnada bu okulların yerleri de değiştirilmemiştir. Dönüşümün yaşandığı sırada enstitülerin tarımsal ve endüstriyel faaliyetleri durdurulmak suretiyle 1947 yılında ders programlarındaki kültür derslerinin saatleri arttırılmıştır. 1954 yılında İlköğretim Okulları şeklinde isimleri üzerinde değişikliğe gidildiği sırada da yer seçimleri konusunda herhangi bir değişiklik yapılmamıştır.

\subsection{Enstitülerde Komünizm Propagandası İddiaları}

Enstitülere yönelen eleştirilerin bir diğer ağırlık noktası; öğretmenlerin, öğrenciler arasında komünizm propagandası yaptığı ve öğrencileri komünist yayınları okumaya zorladıkları iddialarıdır.

$\mathrm{Bu}$ doğrultuda öne sürülen iddialar şu başl1klar altında toplanabilir:

1. Enstitü kütüphanelerindeki kaynaklar arasında Rus klasikleri ve fakirlik hakkında yazılmış romanların ağırlıkta olması,

2. Enstitü idarecileri ve öğretmenleri tarafından insanların dini hassasiyetlerine, inançlarına ve mukaddesatlarına eleştirilerin yapıldığı iddiaları,

3. Enstitü binalarının dönemin Sovyet Rusyasından ilhamını aldığı iddiaları,

Volume 12

4. Enstitülerde uygulanan iş içinde eğitim ilkesini komünizmin getirdiği bir öğreti olarak kabul görülmesi,

5. Enstitü müdürleri tarafından öğrencilerin komünist vb. yayınları okumaya zorlanmaları.

Talip Apaydın, ülkede çok partili hayata geçilmesi ile birlikte oluşan gerginliğin boşaldığı sahalardan birisi olarak gördüğü enstitülerdeki gergin ortamı şu şekilde nakletmektedir: "İtişmelerin iyice yoğunlaştığl günlerde bir toplantıda, durum Genel Müdüre de (İsmail Hakkı Tonguç) açıklandı. Bir arkadaşımız kalktı: efendim biz birbirimizi yiyoruz, dedi. Biz birbirimizi boğazlayacak hale geldik. Kimimiz sağcı olduk, kimimiz solcu...Bunu biliyor musunuz? Enstitüden her gün şikayetler, ihbarlar gidiyor. Şu toplantıda konuşulanlar bile yarın yerine ulaştırılacak. Emniyete, milletvekillerine, hatta Büyük Millet Meclisi Başkanı'na ulaştırılacak. Nedir bu hal? Bize bir yol gösterin. Ne olacaksak bunu bize söyleyin. Hakkı Tonguç acılı bir yüzle dinledi bunları. Sonra uzun uzun kafasını salladı. Ben sizinle bu konuda kapalı-açık çok konuştum, dedi. Siz ateşle oynuyorsunuz. Yapılamaz sanıyorsunuz, ama bir gün bu enstitüleri kapatırlar. Hiç değilse temelden değiştirirler. Siz okudunuz, kurtuldunuz ama sizden sonraki köy çocukları okuyacak okul bulamazlar. Anlıyor musunuz? Aklınızı başınıza toplayın. Binanın temelini oyan fare olmaktan vazgeçin. Köy enstitülerini siz köy çocukları kendiniz yıkacaksınız, dikkat edin...,

\footnotetext{
${ }^{36}$ Kaya, Insan Yetiştirme Düzenimiz, s. 306.

${ }^{37}$ Apaydın, Köy Enstitüsü Yılları, s. 198-199.
} 


\subsection{Enstitülerin Amerika İdaresi Etkisi Altında Kurulduğu İddiası}

Türk-Amerikan ilişkilerinin kritik noktaya ulaştığı sırada Akşam gazetesi yazarı İlhami Soysal, enstitülerin kuruluş süreci ile Amerika idaresi arasında; bazı Türk eğitimcilerinin köy eğitimi konusunda eğitim almak üzere, 1932-1933 yıllarında Amerika'ya gönderilmiş olmaları ve bu kurumların kuruluş süreçlerini başlatanların Amerika'dan dönen bu uzmanlar oldukları, ilk enstitüsü olan Kızılçullu Köy Enstitüsü'nün bina ve arazisinin daha önce burada faaliyet göstermiş olan Amerikalılar tarafından çok ucuz fiyatla Maarif Vekâlet'ine devredilmiş olması $^{38}$ gibi bu türden görüşlerin ortaya atılmış olması iddianın ortaya atıldığ 1 1968'li yıllar açısından manidardır. Çünkü bu esnada Kıbrıs meselesi nedeniyle, Amerika Birleşik Devletleri Başkanı Johnson, Başbakan İsmet İnönü'ye Türkiye-Amerika ilişkilerini zedeleyici mahiyette bir mektup kaleme almıştır. Bu durum ise enstitü karşıtı bazı çevrelerce de kullanılmaya çalışılmıştır ${ }^{39}$.

Bütün eleştirilere rağmen, enstitüler çalışmalarına devam etmiş, Cumhurbaşkanı İnönü her eleştiri karşısında İsmail Hakkı Tonguç'a destek vermiş ve enstitülere daha fazla kız öğrenci alınması için uğraşmıştır. Cumhurbaşkanı İnönü, "İlköğretim meselesinin bir demagojiye kurban edilmemesi için bütün kuvvetimizi kullanacağız" söylemini her fırsatta vurgulamıştır. Mehmet Başaran'ın yaşanılan gelişmelere 1şı tutacak olan ifadeleri ise şu şekildedir: "Seçim propagandalarında seçimden sonra, Enstitüler demagoji canavarının önüne atılmıştı. Kazananlar da yitirenler de, Enstitülere saldırlyordu. Recep Peker'in hükümet programında "Köy Enstitülerinin daha milli bir hale getirileceği yazılıydı. Ölçünün kaçırıldığını anlayan Peker, Adana konuşmasında enstitüleri rejimin iki büyük başarisından biri sayarak, durumu düzeltmeye çalıştıysa da Vatanı muzır faaliyetlerden temizleme eylemi" başlatılmış bulunuyordu. Asıl amaç köyde kentte egemen çevrelerin rahatını bozmaya çalışan Enstitüleri ylkmaktı" ${ }^{, 40}$.

Buna rağmen, eleştiriler her geçen gün artmış, ülkeye demokrasi fikrinin gelmesi siyasî açıdan karışıklıklara sebep olmuş ve CHP bu husustaki ağırlığını kaybetmiştir.

\subsection{Enstitülerin Çevre Köylerle İlişkileri}

Nazif Evren, Dicle Köy Enstitüsü’nde görev yaptığı sırada 1945 yılında yaşandığını iddia ettiği şu iki çarpıc1 örneğe yer vermektedir: "İlk yllda, tecrübesizliğimizden olacak, iki at, iki öküzden oluşan hayvanlarımızın kışlık yiyeceği saman ve otu yeteri kadar depolayamamışız. Klşın biraz da uzun sürmesi hayvanların yiyeceklerinin bitmesine neden oldu. Çevreden ot vel saman gibi yiyeceklerden hiç olmazsa birini bulup hayvanlar bahara kadar çıkarmak gerekiyordu. Araştırdık, hiç kimse öyle bir şey satmıyordu. Bu yokluk telaşı içindeyken, bir gün enstitü alanına yüklü üç devenin geldiğini gördüm. Develere ot yüklüydü. Kimseye sormadan deveci develerini enstitü alanına ıhtırdı ve otları indirdi. Yanlarına uğradım, niçin geldiklerini, bu otları niye getirdiklerini sordum. Yanıtları: "Beg duyduk ki mallarınız yemsiz kalmış. Biz komşuyuz, bunlarl getirdik" dediler. ${ }^{41}$

Enstitünün burada farklı bir işlevine daha işaret etmek mümkün, Nazif Evren Dicle Köy Enstitüsü'nde görev yaptığı sıra gerek ülkenin gerekse özelde bölgenin önemli bir gerçeğine de şahitlik etmektedir. Kan davası ve bundan vazgeçirilen bir öğrenci özetle şu ifadeleri nakletmektedir: "Çevremize giren illerin köylerinde kan gütme geleneği (Kan davasi) bugün olduğu gibi o gün de yoğundu. Bu işi çocuklara yaptırlyorlardı. Çocukların yaşı küçük olduğu

\footnotetext{
${ }^{38}$ Tonguç, Devrim Açısından Köy Enstitüleri ve Tonguç, s. 559.

${ }^{39}$ Kaya, İnsan Yetiştirme Düzenimiz, s. 310-311

${ }^{40}$ M. Başaran, Özgürleşme Eylemi Köy Enstitüleri, Cumhuriyet Kitapları, İstanbul 2003, s. 99-100.

${ }^{41}$ Nazif Evren, Poyraz Köyünden Köy Enstitüleri'ne, s. 78-80.
} 
için ceza süresi az oluyor, belli bir süre sonra hapisten çıkyordu. Çermik köylerinden bir ögrenciye babası hasımlarından birini öldürtmek istiyordu. Bunu öğrenmiştik. Öğrenci bir süre izin istedi, vermedik. Bütün ögretmenler enstitüden kaçmaması için önlem aldık. Derslerde de kan davasının kötülüğ̈ hakkına konuşmalara yer verdik. Öğrencinin babası gelip, bazı mazeretler göstererek çocuğuna izin istedi, vermedik. Sonunda öğrencinin yaş durumu yükseldi, okulu bitirdi. Köyünün bağlı olduğu ilden başka bir ilde görev aldl. Babası her şeyini satarak onun bulunduğu ile göç etti. Bu suretle aile fertleri vurmak ve vurulmaktan kurtuldular. Yine Mardinli bir öğrencimiz de köyünü terk etti, okulu bitirdikten sonra başka bir yerde görev aldı. Şimdi emeklidir. Kapısının üzerine adını bile yazmamaktadır. Köyünden hiç kimseye mektup yazmamaktadır." 42

\section{Kuşakların Gözüyle Köy Enstitüleri’nin Kapatılması}

Köy Enstitüleri'nin kapatılması ifadesinden, kapatılmasından ilk kapatma sözcügünün gündeme gelişi ile kapanış arası dönem algılanmıştır. Meclis'te kabul tarihî olan ve resmen Köy Enstitüsü adının geçtiği 17 Nisan 1940 tarihînden, Köy Enstitüsü adının resmen kaldırıldığ 1954 yılı başlarına kadar geçen süre anlaşılır. Buna göre köy enstitüleri 17 Nisan 1940'ta kurulmuş, 1954'te kapatılmıştır ${ }^{43}$. Köy Enstitüleri'nin kapatılma sürecinin oldukça uzun sürdügü dikkati çekmiştir. Meclisin, üzerinde enstitülere yönelik oluşan baskılar nedeniyle farklı gerekçeler gösterilmek suretiyle sistemi daha kısa sürede devre dışı bırakabilmesi mümkün olmakla beraber, 1945'te sisteme karşı olanların Meclis'teki temsilcilerinin sanıldığından çok olduğu anlaşılmıştır. Bununla birlikte kitlesel karşı koyma olasılığına engel olmak için yavaş hareket edildiği ve kapatma kararı konusunda daha temkinli davranıldığ yorumunu yapmak mümkündür.

Enstitülere ilişkin 4274 sayılı yasa konuşulduğu sırada, Diyarbakır Milletvekili Zeki Mesud Aslan bu rahatsızlığını şu şekilde ifade etmiştir: "Muhterem arkadaşlar. Kanun layihasının istihdaf ettiği en büyük hedef köylerimizin kalkınmasına hizmet etmektir. Şimdi Maarif Vekaleti kendi cephesinden bu davayı ele almıs bulunuyor. Fakat dava o kadar büyük ve o kadar muhtelif cepheli olan bir davadır ki ĕger bütün devlet teşkilatı, devlet organlarl, devlet kuvvetleri bu meselede el birliği yaparak birbirini tamamlayacak şekilde çalışmazlarsa muvaffakiyetin beklenilen ve istenilen derecede olmaması ihtimali vardır." ${ }^{44}$ Köy Enstitüsü müdürlerinden Hürrem Arman'ın yazdığına göre İ. Hakkı Tonguç'un öngörüsü şöyledir: "Söz enstitülerin geleceğinin ne olacă̆ına geldiği zaman hep, tersliklerin nereden çıkabileceğini düşünüyordum. Halktan, köylüden büyük tepkiler gelemezdi... Asıl baltalama devlet yönetimine etkileri olan köşe başlarını tutmuş kişilerin bu kurumları çıkarlarına aykırı görmeleriyle başlayabilirdi. Tonguç'un kesinlikle bildiğim karakter yapısına göre, o başta bulunduğu sürece temel ilkelere etki yapan bir değişiklik olmazdl. Şu halde, onu tatmin ederek uzaklaşttrmak ve yerine getirilecek başka bir kişinin yöneticiliğinde bu kuruluşu kuşa benzetmek yolu tutulabilirdi." 45

3803 Sayılı Köy Enstitüleri Yasası'nın uygulama planı niteliğindeki 4274 Sayılı Yasa, 3-19 Haziran 1942 günlerinde 6 oturumda tartışılmıştır. Tamamı 71 maddeden oluşan yasa üzerinde en yoğun tartışmalar, yasanın 10.11. 25. ve 26. maddelerinin görüşüldüğü sırada yaşanmıştır. 10. maddedeki "Eğitmen ve ögretmenlerin vazife ve selahiyetleri" nin aşırı olduğu vurgulanırken bu hususta en sert eleştiriyi de Eskişehir Milletvekili Emin Sazak yapar: " $B u$ madde muallimlere çok salahiyet veriyor... Bunlara verdiğimiz selahiyet Başvekilde yoktur...

${ }^{42}$ Evren, Poyraz Köyünden Köy Enstitüleri'ne, s. 86-87.

${ }^{43}$ M. Aydoğan, Köy Eğitim Sistemi ve Köy Enstitüleri, Ankara 2006, s. 106.

${ }^{44}$ Aydoğan, Köy Ĕ̈itim Sistemi ve Köy Enstitüleri, s. 158.

${ }^{45}$ Aydoğan, Köy Ĕgitim Sistemi ve Köy Enstitüleri, s. 157. 
Köy Enstitüleri Araştırmaları Üzerine Metodolojik Bir Yaklaşım

Kanun çok güzeldir. Fakat bu madde tamamen yanlıştır.. Bu maddeyi baştan aşăg lağvedelim..." 46

1945 yılına kadar Meclis gündemine “Bütçe Yasaları”nın görüşülmesi sırasında alınan kurumlar ve yöneticileri genelde hep övülmüş, bu kurumların gerekliliğine vurgu yapılmıştır. Ayrıca sistemin iyileştirilmesine yönelik öneriler 1945 yılında çok partili yaşama geçilmesine kadar devam etmiştir. Bu tarihten sonra ise enstitülere yönelik sert bir muhalefet başlamıştır. 25 Mayıs 1945 tarihli Meclis oturumunda Emin Sazak gelişmelerden dolayı endişe duyduğunu bildiren konuşmasını şu şekilde tamamlamıştır: "Okulların kerestesini, çivisini bedava verebiliriz, okul parası için yorganını, ineğini satanlar vardır. Köylü eski köylü değildir, şehirlerde okulun bedava yapıldı̆̆ını bilmektedir. Yalnız çok müteessir olduğumuz bir şey Anayasamız vardır. Bir de partimizin gittiği yol vardır. Arkadaşlar sinuffalan yoktur. Köylerde, yeni yetiştirdiği kafalar bizim gibi az çok çalışan herhangi birisini, memleket için çalışan herhangi birisini yok etmek için mi yetiştirilmektedir? Bu cidden acıdır. Zaten bendeniz takip edilen bu yollardan endişe ediyorum... Nereye gidiyoruz? Tertip edilen adamlarla kendi kendine varlık olacak memleketi bu insanlarla mı idare etmeye çalışıyoruz? Benim korktuğum yol bu..." 47

Bununla birlikte, enstitü muhaliflerine göre, kitlesel hareketi engelleyecek kamuoyuda yaratılmalıydı. Köy Enstitüleri'nin aleyhinde kamuoyu yaratmaya olanak sağlayacak uygulamaların sağlanması daha çok savaş yılları içinde olunmasından hareketle hızlandırılmaya çalışılmıştır. Daha çok kırsal kesimin karşı karşıya kaldığı iktisadi yetersizlikten istifade etme yoluna gidilmiştir. Çoğunluğu kırsal sahada yaşayan Türk halkının sisteme karşı tavır alması bu sayede giderek kolaylaştırılmıştır. Bu sahalarda en açık ifadesi ile köylü kesiminin çocuğunun okula gitmesi halinde elindeki iş görecek gücü eksilmiş olacaktı. "Yakın köylerdeki okulların varlığ köyün yaşamında değişiklik mi yaratmıştt? Şehirdeki okulu devlet yapıyorsa köydekini neden yapmıyordu?" gibi söylemler kamuoyu yaratmak için kullanılmıştır ${ }^{48}$.

1946 seçimleri sırasında CHP'nin tutumunun belirsiz olduğunu ve muhalefet karşısında özellikle zor durumda kalındığını ve bu ortamda enstitülerin politik bir malzeme olarak kullanıldığını düşünenler çoğunluktadır. Bunun üzerine parti yönetimi, kendilerine yönelik artan baskılar sonrasında, enstitüleri düzeltme görevini yeni Milli Eğitim Bakanı Şemsettin Sirer'e vermiştir. 24 Aralık 1946 tarihînde Meclis'teki bütçe görüşmelerinde Emin Soysal, enstitülerin "ahlaksızlık, dinsizlik, komünistlik yuvalarl" olduğunu öne sürmüştür ${ }^{49}$. Bu nedenle Sirer'e göre, Yüksek Köy Enstitüsü kapatılmalıydı. Anlaşılacağı üzere, Köy Enstitüleri’ne açıktan karşı koyma özellikle Yüksek Köy Enstitüsü açıldıktan sonra başlamıştır. Çünkü, Yüksek Köy Enstitüsü sistemin beyni konumundaydı. Bu gelişmelerden de anlaşılacağı üzere,

\footnotetext{
${ }^{46}$ TBMM Zabıt Ceridesi, D. 6, C. 26, s. 274; 25. madde ise, köy ve bölge okullarının yapımında, onarılmasında, benzer işlerde mükellefiyet zorunluluğu getirmektedir. Madde esasına karşı çıkılmamakla birlikte, kadınların çalıştırılması, yaş sınırının aşağı çekilmesi, ceza işlerinin kovuşturmasının kimler tarafından yapılacağı ve cezaların tecili gibi konular Meclis gündemini meşgul etmiş, görüşmelerin uzamasına sebep olmuştur. Aydoğan, Köy Ĕ̈itim Sistemi ve Köy Enstitüleri, s. 170.

${ }^{47}$ TBMM Zabit Ceridesi, D. 7, C. 17, s. 318.

${ }^{48}$ Aydoğan, Köy Ĕ̆itim Sistemi ve Köy Enstitüleri, s. 172-173.

${ }^{49}$ Bu husustaki ilk büyük değişiklikle Yüksek Köy Enstitüsü ile ilgili yeni Talim Terbiye Kurulu karar1 5 Nisan 1947 tarihînde yayımlanmıştır. Anlaşılacağı üzere, enstitülerin kapatılış sürecine giden yol ilk olarak CHP tarafından açılmıştır. Alınan bu kararların ardından kapatma kararı ve yapılması gerekenler 27 Kasım 1947 gün 28695 sayı ile Hasanoğlan Köy Enstitüsü’ne bildirilmiştir. TBMM Zabıt Ceridesi, D. 8, C. 3, s. 455-456.
} 
Tonguç’un “Enstitülerin kalbi” dediği Yüksek Köy Enstitüsü’nün kapatılması köy eğitim ve ilköğretim sistemlerine önemli bir darbe vurmuştur. ${ }^{50}$

1947 yılından itibaren Köy Enstitüleri'nde öğrenci azaltılması yoluna gidilmiş; özellikle kız öğrenci sayısında önemli bir azalma yaşanmıştır. Örneğin, 1945-1946 öğretim yılında 14.464 olan öğrenci sayısı; 1947-1948'de 12.892'ye aynı yıllarda kız öğrenci sayısı da 1.396'dan 1.078 'e düşmüsstür. Böylece mezunlar, hem köy hem de ilköğretim alanlarından uzaklaştırılmıştı́ ${ }^{51}$.

$\mathrm{Bu}$ sırada Engin Tonguç yaşanılan bu gelişmelere ilişkin olarak; "Yücel ve Tonguç'un kendilerini ve enstitüleri iftiralardan korumak ve sükunete kavuşmak için değil de, CHP'nin genel politikasındaki bir yön değişikliğinin gereği olarak görevlerinden ayrılmışlardır... İşte Yücel ve Tonguç'un işbaşından ayrılmalarını gerektiren asıl neden, 1946'da CHP içinde ortaya çıkan iktidar değişikliğidir... " şeklinde yorumlamaktadır ${ }^{52}$.

Hakkı Tonguç, CHP politikasındaki yön değişikliğini ve bunun sonrasında görevlerinden ayrılmalarını şu şekilde ifade etmiştir: "1946 seçimlerinden sonra Recep Peker kabinesinde Milli Ĕ̈itim Bakanı olan Reşat Şemsettin Sirer ile işbirliği yapmayacağımı Başbakan'ın Meclis 'te okuduğu beyannamedeki sözlerinden kestirdiğim için vazifemden ayrılmama müsaade etmesini Bakandan rica ettim. Çok geçmeden bazı milletvekilleri ile elbirliği ederek Büyük Millet Meclisi'nde aleyhime tertipler kurmaya çalıştığını hissettim. ${ }^{\circ 3} 1946$ seçimleri sırasında CHP'nin tutumunun belirsiz olduğunu ve muhalefet karşısında ne yapacağını bilemez halde kaldığını düşünenler olmuştur. Dolayısıyla bu ortamda enstitüler politik argüman olarak kullanılmıştır. Köy okullarının yapımı ve öğretmen yetiştirme düzeni CHP'yi sarsmış; DP, köylülere toprak dağıtmayı vaad etmiştir ${ }^{54}$.

Volume 12

Issue 3

June

2020

Çok partili yaşama geçiş kararı alınır alınmaz muhalifler Celal Bayar önderliğinde kendi partilerini kurmuşlardır. Aynı günlerde CHP içinde de güç değişimi gerçekleşmiştir. 1946 yılında çok partili siyasal hayatın başlamasıyla birlikte; CHP'nin karşısında çok sayıda siyasî parti kurulmuş ve enstitülere yöneltilen suçlamalar da artmıştır. Bu partiler arasında özelikle DP’nin, CHP yönetimini yıpratmak amacıyla bir koz olarak Köy Enstitüleri'ni kullanmaya

\footnotetext{
${ }^{50}$ Enstitüler ve mezunları aleyhinde tasfiye girişimlerinin giderek yoğunluk kazandığı dönemde, Çifteler Köy Enstitüsü’nde komünistlerin örgütlenmeye gittikleri, Hasanoğlan Yüksek Köy Enstitüsü’nde komünist öğrencilerin bulunduğu ihbarları gerek enstitü öğrencileri gerekse kamuoyu üzerinde tesir uyandırmış, öğrenciler arasında sağcı-solcu, milliyetçi-komünist ve ilerici-gerici ayrımı ve sürtüşmeleri yaşanmıştır. Enstitülerde komünizm propagandası yapıldığı yolundaki suçlamalara Fevzi Çakmak Paşa'nın da dahil olması, kamuoyunu meşgul edecek olan Hasan Âli Yücel-Kenan Öner davasına neden olmuştur. Davanın başlamasına etki eden gelişme Bağımsız Milletvekili Fevzi Çakmak'ın "solcuları koruyanın Halk Partili eski bir Milli Eğitim Bakanı olduğunu” ileri sürmesi ile başlamıştır. Bu gelişme üzerine Hasan Âli Yücel, 5 Şubat 1947 tarihînde Ulus gazetesine yaptığ bir açıklamada "Bu ben miyim?" diye sorunca, cevabı Fevzi Çakmak yerine DP İstanbul İl Başkanı Kenan Öner, "Evet sensin" diyerek Yücel'i komünistleri müdafaa etmek ve komünizmin yayılmasına yardımcı olmakla suçlamıştır. Yücel ise haksızlığa uğradığı gerekçesi ile Kenan Öner aleyhine dava açmıştır. Bkz. AYSAL, “Anadolu'da Aydınlanma Hareketinin Doğuşu: Köy Enstitüleri”, s. 279-280.

${ }^{51}$ M. Aydın, Köy Enstitüleri ve Toplum Kalkınması, Anı Yay., Ankara 2007, s. 112; 1947'de çıkarılan 5117 ve 5129 sayılı kanunlarla köylerdeki öğretmenlerin enstitülerle bağları kesilmiş, verilen tarım, sanat araç gereçleri geri alınarak, 100 lira aylıklı memur durumuna getirilmişlerdir. İlköğretimi güçlendirmek amaciyla hazırlanmış olan "On yıllık plan” uygulamasından da vazgeçilmiştir. M. Başaran, Özgürleşme Eylemi Köy Enstitüleri, Cumhuriyet Kitaplar1, İstanbul 2003, s. 102.

${ }^{52}$ E. Tonguç, Köy Enstitülerinin İzinde, Güldükeni Yayınevi, Ankara 2003, s. 201-202.

${ }^{53}$ Tonguç, Köy Enstitülerinin İzinde, s. 203.

${ }^{54}$ N. Koç, , Türk Kültür Tarihî İçinde Köy Enstitüleri, Ege Üniversitesi Sosyal Bilimler Enstitüsü, (Yayınlanmamış Doktora Tezi) .İzmir 2007, s. 407.
} 
başlaması çok gecikmemiştir. İlginç olan taraf ise, suçlamalar CHP içindeki milletvekilleri tarafından da desteklenmiştir ${ }^{55}$.

1947 yılında çıkarılmış olan 5117 ve 5129 sayılı kanunlarla; "17.4.1940 tarihli ve 3803 sayll ve 19.6.1942 tarihli ve 4274 sayll kanunlar gereğince kendilerinin işlemesi için okul arazisi tahsis edilememis olanlara, Enstitüden mezun olanlardan köy ögretmenliğine tâyin edilenlere hizmete başladıkları tarihten başlayarak altı ay müddetle, istihsal tazminatı adı ile ayliklarıyla birlikte ayda 25 lira..." ${ }^{, 56}$ verilmesi karara bağlanarak öğretmene toprak verilmesi güçleştirilmiş, öncesinde dağıtılan kitapların, hayvanların ve diğer malzemelerin geri alınması yoluna başvurulmuştur. 1947 ve 1948 yıllarında çıkarılan 5012 ve 5210 sayılı kanunlarla, köylünün okul yapımı yükümlülüğünden çıkartılması sağlanmıştır. 1947-1948 ders döneminde de Yüksek Köy Enstitüleri de kapatılmıştır.

Çifteler Köy Enstitüsü ve Hasanoğlan Yüksek Köy Enstitüsü mezunu Talip Apaydın, Köy Enstitülerinin kapatılması hakkında şu ifadelere yer vermiştir: "Köy Enstitüleri sistemi devam etseydi köylümüzün, halkımızın en başta ekonomik durumu düzelecekti. Çağdaş bir yaşama ulaşacaktı. Fakat halkın yaşamının gelişmesini istemeyen güçler kapattılar. Köy Enstitülerini çalışmaz hale getirdiler. Halkımız gelişemedi, hâlâ geri kalmışlıktan kurtulamadı. Bütün dünyaya borçlu, halkın büyük çoğunluğu yoksul, köyler kentlere akın etti, kentler bozuldu, genel olarak geri kalmışlıktan kurtulamadı. Pek çok arkadaşımız başarılı oldular. Çok daha başarılı olabileceklerdi, bırakmadılar, değiştirdiler, sürdüler. Onun için Köy Enstitüleri aslında amacına tam ulaşmamıştır, ulaş̧ırılmamıştır, kesilmişstir. Yani bıraksalardı da yasada olduğu gibi 20 yll kalabilseydi o köyde; o köyü kökten değiştirecekti. Halkın değişmesini, çağdaşlaşmasını istemeyen, bunda çıkarı olan güçler, köy ă̆aları, çirkin politikacı dediğimiz o ilkel politikacı tipleri, yani memleketini değil de kendi çıkarını düşünen tipler. Bunlar bırakmadılar, Köy Enstitülerini kapattılar. ${ }^{, 57}$

Enstitüleri'nin kapatılması konusunda, son derece gerçekçi bir görüş ileri süren Tanilli’ye göre; “Köy Enstitüleri'ni kuran ve kapatan iktidarın aynı iktidar, CHP iktidarı olması rastlantı değildir. Bununla beraber, burjuvazi adına hareket eden küçük-burjuva, aydın-bürokrat kadroların da sıralarda artık ya bir bölümüyle burjuvaziyle bütünleştiğini ya da tarihsel misyonlarını yitirdiklerini söylemiş olalım. Özetle, Köy Enstitüleri, Türkiye'deki sınıfsal gelişmelerin mantığı bakımından yıkılmaya mahkumdu." 58 Doğan Avcioğlu ise, Köy Enstitüleri ve toprak reformu olmak üzere iki inkılâpçı hareketten beklenen neticenin alınamamasının tarihî arka planında tefeci tüccarların, ağalık ve şeyhlik düzeni devamından yana olanların ve tutucu bürokratlarının demokrasinin işleyişini engellemelerinin neticesi olduğuna işaret etmektedir ${ }^{59}$.

Köy Enstitüleri yerini 27 Ocak 1954 tarihînde çıkarılan 6234 Sayılı Kanunla sistem tamamen yıkılarak \%25 oranında kentlerden de öğrenci alımına başlanarak "illköğretmen Okulları”na, bırakmıştır ${ }^{60}$. Statü yönünden kentlerdeki öğretmen okulları ile aynı statüye

\footnotetext{
5521 Temmuz 1946 yılında yapılan genel seçimlerden sonra CHP'deki sağ kesim hem parti içinde kalmış hem de partiye ve çevreye karşı yeni bir tavır almıştır. CHP'deki sağ kesim, DP karşısında yer almak adına partiyi sağa kaydırmak için birleşmiştir. DP, CHP'yi ve özellikle Köy Enstitüleri'ni eleştirmiş, CHP ise bunların halkın yararına olduğunu anlatmak yerine "düzelteceğiz" diyerek kendi yaptıklarını savunamamıştır. Türkoğlu, Tonguç ve Enstitüleri, s. 503.

${ }^{56}$ TC Resmî Gazete, 26 Haziran 1947, Say1: 6642, s. 12561.

${ }^{57}$ Aydın, Köy Enstitüleri ve Toplum Kalkınması, s. 114-115.

${ }^{58}$ A. Arayıc1, Kemalist Dönem Türkiye'sinde Eğitim Politikalarl ve Köy Enstitüleri, Ceylan Yay., İstanbul 2002, s. 260.

${ }^{59}$ Doğan Avcıŏlu, Türkiye’nin Düzeni (Dün-Bugün-Yarın), Cilt: I, 5. Baskı, Bilgi Yayınevi, Ankara 1971, s. 330.

${ }^{60}$ TC Resmi Gazete, (Tarih 04.02.1954), Sayı: 8624; Düstur, Tertip: 3, Cilt 35, s. 274.
} 
getirilmiş ve buralara şehirden öğrenciler de alınmaya başlamıştır. Özellikle tarım ve endüstriyel faaliyetlerde, okulun sevk ve idaresinde öğrencilere sorumluluk verme ilkesinden uzaklaşan yeni öğretmen okulları bu becerilerden yoksun öğretmenler yetiştirmeye başlamışlardır. Türk eğitim sistemine önemli derecede katkı sağlamış olan bu müesseseler aynı zamanda Türkiye'de siyasî, idarî, iktisadî, sosyo-kültürel alanlarda da tesir yaratmıştır.

\section{Sonuç}

Araştırmamız neticesinde kesin olmamakla beraber bazı yargılara ulaşılmıştır: Kırsalın yeniden canlandırılması üzerine hararetli münakaşalar Köy Enstitüleri'nin kurulmasından öncesine dayanmakla birlikte, esasında, bugün de enstitüler özelinde savunulmakta olan farklı duruşların tarihî bir arka planı vardır. İslam karşıtı komünist fikirlerin yuvaları oldukları yönündeki ön yargilar nedeniyle, "kalifiye insanlar tarafindan idare edilen ilkel kurumlar" ve iyi niyetten yoksun olduklarına ilişkin fikirler üzerinden enstitülere saldırılmıştır ve saldırılmaya devam edilmektedir. Toplumda köklü altyapı değişikliklerinin bir üst yapı kurumu olan eğitimle gerçekleştirilmesinin tamamılla sağlanamayacağ 1 hususu enstitülere yapılan eleştirilerden bir diğeridir. Bu eleştirilerin kısmen doğru olduğu bir hakikat olmakla beraber her şeyden evvel inkılâpların geniş halk kitlelerine ulaştııılmasına hizmet edecek olan Köy Enstitüleri'nin ve diğer müesseselerin inkılâpları isteyecek bilinçlenmiş toplum yapısına zemin hazırladığı açıktır. Bu bilinçli toplum yapısı enstitülerin gelişim süreci yıllarında, tarım sektöründe yaşayan nüfus azalma eğilimi göstermesine rağmen, tarımdan geçinenlerin toplam nüfusa oranı \% 77'ydi. Ülke ithalatının \% 80'ini hala tarımsal ürünler oluşturuyordu. Tarımsal mal ihracat oranı ise sadece \%10'du. 1950 tarım sayımı sonuçlarına göre, tarımda çalışanların \%17'si toprağa sahip değildi. Bu hassa aynı zamanda kırsal canlanmanın bu boyutunu da kapsamaktaydi.

Volume 12

Diğer taraftan hazırladığımız çalışmada Köy Enstitüleri'nin destekçileri arasında da faklı düşüncelerin olduğunu gördük. Bahsi geçen destekçiler enstitülerin yeniden açılmasını desteklememekle beraber, bütün Türk eğitim sisteminin tamamıla enstitülerindeki uygulamaları 1şığında reform yapılması gerektiği üzerinde ısrar etmişlerdir. Aşırıya kaçmamakla birlikte bu karşıt görüşlerin tezleri sıklıkla ulusal basında ve bilimsel dergilerde ispatlanmaya çalışılmaktadır. Bu çevreler tarafından Köy Enstitüleri ile insan yetiştirme düzeninin büyük ölçüde yoluna girdiği, kapatılmalarının da kamuoyunda bugün karşılaşılan noksanlıkların başlıca nedeni olduğu son y1llarda daha çok gündeme taşınmıştır. Kanaatimce cumhuriyet tarihîmizin en önemli başarılardan birisi olarak, telakki edilen enstitülere bugün dahi sahip çıkılıyor olması, içinde yaşadığımız dönemin şartları için de son derece önemlidir. Sistem kurumlaşmamışsa ya da kurumlaşma kökleşememişse, kişilere bağlı yapılaşmanın kalıcı olamayacağını belli etmiştir. Yaşanan gelişmeler yönetime yerleşmiş etkili bir azınlığın halkın uyanmasından korktuğunu, aydınlanmayı kendileri için tehlikeli gördüklerini meydana çıkarmıştır. Enstitülerin en çağdaş yanları ise eleştiri konusu yapılarak kapatılmıştır.

Öncelikle tarihîn tanıklarına kulak vermek ve en önemlisi "dinlemeyi ögrenmek" en başta insanî bir beceridir. Bu açıdan Türkiye'de bugün ve gelecekte sözlü tarihîn önünde açılan zengin bir potansiyel bulunduğu kanaatini taşımaktayım. Öncelikle enstitüler genelinde Türkiye'de yaygınlık kazanacak olan sözlü tarih çalışmaları sayesinde, bu eğitim kurumlarının geçmişini daha kapsamlı olarak anlamak ve eğitim tarihîmize ilişkin bellekler yaratmak mümkün olabilir. Bu sayede enstitülere yönelik düşmanlıkların bugün hala bazı çevrelerce devam ettirile gelmesi bu boşluktan kaynaklanmaktadır. 
Köy Enstitüleri Araştırmaları Üzerine Metodolojik Bir Yaklaşım

\section{Kaynakça}

ARAYICI,. A., Kemalist Dönem Türkiye'sinde Eğitim Politikaları ve Köy Enstitüleri, Ceylan Yay., İstanbul 2002.

AVCIOĞLU, Doğan, Türkiye 'nin Düzeni (Dün-Bugün-Yarın), Cilt: I, 5. Bask1, Bilgi Yayınevi, Ankara 1971.

AYDIN, M., Köy Enstitüleri ve Toplum Kalkınması, Anı Yay., Ankara 2007.

AYDOĞAN, M., Köy Eğitim Sistemi ve Köy Enstitüleri, Ankara 2006.

BAŞARAN, M., Özgürleşme Eylemi Köy Enstitüleri, Cumhuriyet Kitapları, İstanbul 2003.

BLOCH, Marc, Tarihîn Savunusu ya da Tarihçilik Mesleği, 2. Baskı, (Çev. M. Ali Kılıçbay), Ankara, 1994.

BURKE, Peter, Annales Okulu, (Çev: Mehmet Küçük), Ankara, 2002.

BURKE, Peter, The French Historical Revolution: The Annels School 1929-1989, Polity Press, Cambridge 1990.

CAUNCE, Stephen, Sözlü Tarih ve Yerel Tarihçi, (Çev: Bilmez Bülent Can-Alper Yalçınkaya), İstanbul 2001.

COLLINGWOOD, R.G., Tarih Tasarımı, (Çev: Kurtuluş Dinçer), Gündoğan Yayınları, Ankara 1996.

DİE, Milli Ĕgitim Hareketleri (1927-1966), Ankara 1967.

Düstur, Tertip: 3, Cilt 35.

EVREN, Nazif, Poyraz Köyünden Köy Enstitüleri’ne, Güldikeni Yay., 2. Baskı, Ankara 1997.

GEDIKLİOĞLU, Ş, Türkiye'de Yaygin Eğitimden Çağdaş Eğitime, Kadığlu Matbaası, Ankara 1991.

IGGERS, George G., Yirminci Yüzyılda Tarih Yazımı, (Çev: Gül Ç. Güven), İstanbul 2003.

İLYASOĞLU, Aynur, "Yakın Dönemde Tarihe İlginin Farklılaşması Sürecinde Sözlü Tarih Alanının Türkiye'deki Gelişimine Bir Bakış”, Kuşaklar Deneyimler Tanıklar: Türkiye'de Sözlü Tarih Çalışmaları Konferansı (26-27 Eylül 2003), (Yay. Haz: Aynur İlyasoğluGülay Kayacan), İstanbul 2006, ss. 15-22.

KARAÖMERLIOĞLU, Asım, Orada Bir Köy Var Uzakta (Erken Cumhuriyet Döneminde Köycü Söylem), 2. Bask1, İletişim Yayınları, İstanbul 2011.

KAYA, Yahya Kemal, Insan Yetiştirme Düzenimiz, 4. Baskı, Ankara 1984.

KİRBY, Fay, Türkiye'de Köy Enstitüleri, (Çeviren: Niyazi Berkes), 4. Bask1, Tarihçi Kitabevi, İstanbul 2012.

KOÇ, N., Türk Kültür Tarihî Iç̧inde Köy Enstitüleri, Ege Üniversitesi Sosyal Bilimler Enstitüsü, (Yayınlanmamış Doktora Tezi) .İzmir 2007.

MEB Talim ve Terbiye Başkanlığı, 1923-1982 Öğretim Ylllarl Okul, Öğretmen, Öğrenci Sayllarl, Ankara 1982. 
AYSAL, Necdet, "Anadolu'da Aydınlanma Hareketinin Doğuşu: Köy Enstitüleri”, Ankara Üniversitesi Türk Inkılâp Tarihî Enstitüsü Atatürk Yolu Dergisi, S. 35-36, Mayıs Kasım 2005.

ÖZBARAN, Salih, Tarih, Tarihçi ve Toplum, İstanbul 2005.

TBMM Zabit Ceridesi, D. 8, C. 3, s. 455-456.

TBMM Zabıt Ceridesi, Devre: 6, Cilt:10; C. 26.

TBMM Zabut Ceridesi, Devre: 7, Cilt: 17.

TC Resmî Gazete, 26 Haziran 1947, Sayı: 6642.;( 4 Şubat 1954), Sayı: 8624.

THOMPSON, Paul, "21. Yüzyılda Sözlü Tarih İçin Potansiyeller ve Meydan Okumalar", Kuşaklar Deneyimler Tanıklar: Türkiye'de Sözlü Tarih Çalışmaları Konferansı (26-27 Eylül 2003), (Yay. Haz: Aynur İlyasoğlu-Gülay Kayacan), İstanbul 2006, ss. 23-37.

TONGUÇ, E., Köy Enstitülerinin İzinde, Güldükeni Yayınevi, Ankara 2003.

TONGUÇ, E., İsmail Hakkı, Canlandırılacak Köy, İstanbul 1938.

TONGUÇ, İsmail Hakkı, Mektuplarla Köy Enstitüsü Yılları (1935-1946), (Yay. Haz. Engin Tonguç), 2. Bask1, İstanbul 1990.

TÜRKMEN, İsmet, "Rural Revitalization and The Village Institutes Experience in Turkey (1940-1954)", European Journal of Multidisciplinary Studies, (September-Decembery 2017), V. 6, Nr. 1, ss. 17-22.

TÜRKOĞLU, Pakize, Tonguç ve Enstitüleri, Türkiye İş Bankası Kültür Yay., 3. Bask1, İstanbul 2007.

VERSCHOYLE, T., "Education in Turkey", International Affairs (Royal Institute of International Affairs 1944-), Vol. 26, No. 1 (Jan., 1950), ss. 34-57. 